\title{
ТЕЛЕМЕДИЦИНСКОЕ МОНИТОРИРОВАНИЕ ОРТОДОНТИЧЕСКИХ ПАЦИЕНТОВ ШКОЛЬНОГО ВОЗРАСТА В СИСТЕМЕ СПЕЦИАЛИЗИРОВАННОЙ ДИСПАНСЕРИЗАЦИИ
}

\section{Е. А. Биднюк, Л. С. Годлевский, Н. Р. Баязитов, А. В. Ляшенко \\ Одесский национальный медицинский университет}

У дітей, яким для усунення ортодонтичних захворювань застосовували брекет-системи, проводили моніторинг стану зубів за допомогою аналізу цифрових зображень. Встановлено можливість ранньої діагностики початкових форм карієсу, пародонтиту, контроль динаміки виправлення стану зубних рядів, скорочення загального терміну лікування в 1,5-2,5 раза та запобігання рецидивам у період після зняття брекет-системи.

Распространенность зубочелюстных аномалий и деформаций в различных регионах СНД колеблется от 30,9 до $76,5 \%$, а необходимость применения брекет-технологий в период сменного прикуса имеет место у 42,0 \% детей $[2,4]$. Кроме того, около $80 \%$ детей в возрасте до 12 лет имеют пораженные кариесом постоянные зубы, а к 15 годам распространенность данной патологии охватывает $88 \%$ детей $[1,4,6]$. При этом более половины 15-летних подростков имеют признаки поражения тканей пародонта. Проблема профилактики заболеваний зубов в детском возрасте может быть решена на основе проведения профилактических диспансерных осмотров, которые сегодня проводятся в плановом порядке в организованных группах детей возрастом от 6 до 14 лет [4, 5, 6].

Целью настоящего исследования было изучение возможностей информационной телемедицинской технологии консультирования пациентов, которым проводили коррекцию зубных рядов с помощью брекет-технологий.

Сегодня профилактический стоматологический осмотр (диспансеризация) представляет собой периодически повторяющийся осмотр пациента, в том числе и детей, периодичность которого (дважды в год) базируется на средних показателях латентного периода формирования наиболее распространенного заболевания - кариеса зубов [1, 3]. Подобная периодичность, таким образом, не соответствует современным технологическим возможностям, которые позволяют проводить более регулярный, более тщательный сбор информации о пациенте. Посуществу, речь сегодня должна идти о замене диспансерного наблюдения мониторингом состояния здоровья пациента на основе широкого внедрения современных средств удаленного контроля здоровья пациента.

Опыт работы телемедицинской сети Одесского региона за период 2009-2012 года по вопросам () Е. А. Биднюк, Л. С. Годлевский, Н. Р. Баязитов, А. В. Ляшенко консультирования пациентов в рамках стоматологической диспансеризации свидетельствует, что показания к проведению консультаций были следующими:

1. Наличие выраженной патологии твёрдых тканей зубов (множественный кариес и его осложнения КПУ >/ 8, гипоплазия эмали, флюороз).

2. Ортодонтическая патология средней и тяжёлой степени (прогенический, прогнатический, открытый, глубокий, перекрёстный прикус, ретениро- ванные зубы, сверхкомплектные зубы, выраженная скученность зубов и т.д.).

3. Патология пародонта (гингивит, пародонтит).

4. Патология височно-нижнечелюстного сустава.

5. Наличие укороченных уздечек верхней губы, языка, мелкого преддверия полости рта, макроглоссии.

6. Наличие вредных привычек.

7. Патология ЛОР-органов.

8. Бруксизм.

9. Нарушение дикции.

10. Сопутствующая патология ЖКТ, ССС, опорно-двигательной системы, эндокринной системы.

11. Обсуждение и формирование тактики совместного ведения пациентов специалистами различных профилей.

После определения показаний к проведению телемедицинского консультирования средней медицинский работник телемедицинского кабинета стоматологической поликлиники оформляет направление-заявку на консультацию. В заявку включены: номер школы, класса, идентификационные данные ребенка, данные родителей, данные врача, который определил показания к телеконсультации. Указывают адрес йр-сервера, где находятся данные - результаты обследования пациента.

Для каждого пациента с выраженными зубочелюстными деформациями, наличием сопутствующей патологии СCC, ЖКТ, эндокринной системы, тяжёлыми формами пародонтита, наличием пато- 
логии ЛОР-органов в обязательном порядке создают временное депо данных обследований. При этом пациентов и их родителей через учреждения образования информируют о целесообразности создания временного йр-депо данных, которые необходимы для эффективного длительного наблюдения за пациентами. В направление-заявку включают данные о характере консультации, которую предполагается получить (по какой специальности, синхронное, асинхронное, с участием или без участия пациента, а так же с участием родителей пациента). Заполняют также контактные данные сотрудника, который является ответственным за заполнение направления-заявки на телеконсультирование и достоверность указанных данных.

При оформлении направления-заявки на проведение телемедицинской консультации обязательным является дополнение к ней развёрнутой «Выписки из медицинской карты стоматологического больного для телемедицинской консультации». В этом документе указывают медицинские данные пациента, суть консультации, на которую рассчитывает лечащий врач, и данные специалиста или нескольких специалистов, от которых необходимо

\section{Литература}

1. Годлевский Л. С. Информационное обеспечение профилактического стоматологического осмотра детей / Л. С. Годлевский, Е. А. Биднюк, А. В. Ляшенко // Кибернетика и вычислительная техника. 2011. - Вып. 165. - С. 40-46.

2. Максютенко А. С. Использование современных цифрових методов диагностики хронических периодонтитов и заболеваний слизистой оболочки полости рта при проведении телеконсультаций в стоматологи / А. С. Максютенко, Д. К. Калиновский // Украинский журнал телемедицины и медицинской телематики. - 2008. - Т 6, № 2. - С. 133-136.

3. Організація телемедичної допомоги в закладах охорони здоров'я (методичні рекомендації) / М. В. Голубчиков, получить данную консультацию.

Консультации ортодонтических пациентов, которым проводили лечение с помощью брекет-систем, проводили следующие специалисты (в порядке убывания числа консультаций): ортодонты; хирургистоматологи; пародонтологи; гигиенисты; логопеды; педиатры; эндокринологи; хирурги-ортопеды; гастроэнтерологи; ревматологи; психологи; физиотерапевты.

Исследование эффективности телемониторинга ортодонтических пациентов показало возможность ранней диагностики начальных форм кариеса, пародонтита, возможность контроля динамики достижения требуемого эффекта, сокращение общего периода времени лечения - в 1,5 - 2,5 раза, в сравнении с традиционным применением брекет-системы. Кроме того, достигался эффект уменьшения рецидива после снятия брекет-системы.

Выводы. Полученные результаты свидетельствуют о том, что применение современных информационных систем обеспечивает возможность мониторинга детей, которым применены брекетсистемы для устранения ортодонтических заболеваний, эти системы заменяют традицион-

А.В. Владзимирський, В. Г. Климовицький [та ін.] // МО3 України. - К., 2008. - 70 с.

4. Организация стоматологической помощи населению : учебное пособие для врачейстоматологов / под ред.

А.С. Оправина, А. М. Вязьмина. - Архангельск : Северный государственный медицинский университет.

- 2011. - 519 с

5. Телемедицинские технологии в здравоохранении / Самченко И. А., Годлевский Л. С., Даирбеков О. Д. [и др.] // Республика Казахстан - Україна, Шымкент Одесса : Білім, 2008. - 366 с.

6. First results of the implementation of telemedical service in the Odessa region / L. S. Godlevsky, S. V. Kalinchuk, N. R.Bayazitov [et al.] // Polish Journal of Medical Physics 
Медична інформатика та інженерія 